\title{
IDENTIFIKASI FAKTOR PENYEBAB OBESITAS PADA SISWA SEKOLAH DASAR NEGERI RANDUSARI
}

\author{
Feri Budi Setyawan \\ Program Studi S1-PGSD, Fakultas Ilmu Pendidikan, Universitas Ahmad \\ Dahlan \\ Email: feri.setyawan@pgsd.uad.ac.id
}

\begin{abstract}
Abstrak
Penelitian ini betujuan untuk membahas tentang fenomena obesitas yang terjadi pada siswa Sekolah Dasar Negeri Randusari. Penelitian ini bertujuan untuk mengetahui faktor penyebab obesitas pada siswa Sekolah Dasar Negeri Randusari. Penelitian ini merupakan penelitian deskriptif kuantitatif dengan teknik pengambilan data menggunakan tes pengukuran tinggi badan dan berat badan. Populasi dalam penelitian ini adalah anak pada siswa Sekolah Dasar Negeri Randusari. Teknik analisis data menggunakan Descriptive Statistic Frequencies. Hasil luaran dari penelitian identifikasi faktor penyebab obesitas pada anak adalah hubungan faktor genetik dengan orang tua, tidak seimbangnya asupan makanan yang dikonsumsi dengan energi output yang harus dikeluarkan, dan kurangnya melakukan aktifitas olahraga juga menjadi faktor penyebab lain terhadap kegemukan ini adalah modul pembelajaran seni rupa dan keterampilan pada siswa Sekolah Dasar Negeri Randusari.
\end{abstract}

Kata kunci: faktor penyebab obesitas

\begin{abstract}
The purpose of this research is to discuss about the obesity phenomenon which occurred in elementary school students of the country Randusari. This research aims to know the causes of obesity in elementary school students of the country Randusari. This research is quantitative descriptive research with engineering data retrieval using the test measurements of height and weight. The population in this research is the child in elementary school students of the country Randusari. Data analysis techniques using Descriptive Statistics Frequencies. The results of the research of the identification of external factors the causes of
\end{abstract}


obesity in children is the relationship of genetic factors with the parents, not the share of food intake with energy output being consumed must be issued, and the lack of performing activities the sport has also become another cause factor against obesity it is art learning modules and skills at elementary school students of the country Randusari.

Keyword: factor in the causes of obesity

\section{PENDAHULUAN}

Pada era modern, tidak sedikit orang yang memperdulikan pola hidup sehat (Onis, 2008). Kebanyakan dari mereka akan menyadari arti penting kesehatan apabila telah mengalami sakit. Sakit dan penyakit selalu timbul karena dua sebab, (1) Faktor internal atau faktor keturunan. Hal ini merupakan sebuah kecenderungan, apabila orang tua menderita diabetes atau tekanan darah tinggi maka anak yang dilahirkan akan memiliki kecenderungan untuk menderita penyakit tersebut. Pernyataan tersebut tidak berarti kalau orang tuanya tidak menderita suatu penyakit, demikian juga anak-anaknya, namun persentasenya lebih kecil. (2) Faktor eksternal, yaitu pola makan dan gaya hidup. Erat kaitannya dengan faktor penyebab kedua, masalah atau gangguan yang sering dialami oleh sebagian orang adalah kegemukan atau yang biasa di kenal dengan obesitas.

Obesitas merupakan permasalahan serius yang mulai menjadi perhatian di seluruh dunia. Obesitas merupakan penumpukan lemak yang berlebihan ataupun abnormal yang dapat mengganggu kesehatan (Biro\&Wien, 2010). Obesitas terjadi bila besar dan jumlah sel lemak bertambah pada tubuh seseorang (Onis, 2008)). Obesitas merupakan suatu penyakit multifaktorial yang terjadi di Indonesia akibat akumulasi jaringan lemak berlebihan sehingga dapat mengganggu kesehatan. Kementrian Kesehatan Republik Indonesia tahun 2013 menyatakan bahwa obesitas kini menjadi nasional sehingga menjadi masalah kesehatan yang harus segera ditangani (Kemenkes RI, 2013). 
Salah satu kelompok umur yang berisiko terhadap kejadian gizi berlebih adalah kelompok usia sekolah. Penelitian (Dewi\&Sidiartha, 2013) mengemukakan bahwa dari 50 anak laki-laki yang mengalami obesitas terdapat sebanyak $86 \%$ akan tetap mengalami obesitas dan dari 50 anak perempuan yang mengalami obesitas terdapat sebanyak $80 \%$ akan tetap mengalami obesitas pada masa dewasa. Obesitas permanen cenderung akan terjadi bila muncul pada saat anak berusia 4-11 tahun sehingga sangat diperlukan upaya pencegahan terhadap obesitas sejak dini. Peningkatan angka terhadap kasus obesitas pada anak tersebut tidak hanya terjadi di negara maju, tetapi juga terjadi di negara berkembang.

Apabila peningkatan obesitas terus berlanjut dan tidak ditatalaksana dengan baik maka pada tahun 2025 tidak mustahil penduduk Indonesia akan menyandang gelar "Obesogenik". Obesitas anak jelas menjadi masalah kesehatan yang serius bukan hanya karena keberlanjutannya menjadi obesitas dewasa, tetapi juga karena dampak negatif yang ditimbulkan terhadap kesehatan (Paciorek, et al, 2013). Dampak negatif tersebut antara lain berupa gangguan psikososial yang berakibat pada rasa rendah diri, depresi dan menarik diri dari lingkungan. Selain itu, obesitas menyebabkan gangguan pertumbuhan fisik, gangguan pernafasan, gangguan endokrin, obesitas yang menetap hingga dewasa, dan risiko terhadap penyakit degeneratif. Penyakit degeneratif tersebut antara lain hipertensi, penyakit jantung koroner, diabetes melitus dan sebagainya yang pada akhirnya berujung pada penurunan kualitas hidup dan peningkatan beban ekonomi keluarga dan negara.

Sebagaimana sudah diketahui bahwa anak usia sekolah dasar memiliki karakteristik yang unik. Perkembangan fisik atau jasmani, bahasa, intelektual dan emosional berkembang secara holistik dan saling berkaitan, jika salah satu perkembangan bermasalah dan tidak segera diatasi, maka akan berdampak pada terjadinya masalah pada perkembangan yang lain, begitupun pada obesitas yang merupakan masalah fisik, jika masalah perkembangan fisik ini tidak segera diselesaikan bisa berdampak pada penurunan/perlambatan perkembangan sosial emosional, bahasa maupun kognitifnya

Berdasarkan beberapa hal tersebut, maka dari itu penulis tertarik untuk mengadakan penelitian untuk mengetahui Identifikasi Faktor Penyebab Obesitas Pada Siswa Sekolah Dasar Negeri Randusari.

\section{METODE}

Penelitian ini menggunakan metode penelitian deskriptif kuantitatif. Data yang dikumpulkan merupakan hasil dari 
pengukuran berat badan dan tinggi badan yang selanjutnya dihitung dan dikategorikan berdasarkan klasifikasi obesitas. Teknik analisis data dalam penelitian ini menggunakan perhitungan statistik deskriptif dengan frekuensi dan persentase.

Penelitian ini dilakukan di SD Negeri Randusari Kecamatan Ngemplak Kabupaten Sleman dibatasi pada siswa kelas atas dengan cara mengambil data yang berjumlah 81 siswa dengan mengukur berat badan ideal. penelitian ini adalah semua siswa yang terdaftar di SD Negeri Randusari dari kelas 4 sampai kelas 6.

Teknik pengumpulan data dalam penelitian ini adalah menggunakan angket tertutup, sebelum responden menerima angket, anak akan diukur tinggi badan dan berat badannya kemudian akan dihitung menggunakan metode pengukuran berat badan ideal akan dihitung menggunakan metode pengukuran Indeks Massa Tubuh (IMT).

Teknik analisis yang digunakan adalah analisis deskriptif kuantitatif dengan persentase. Analisis data ini digunakan bantuan software komputer (SPSS).

\section{HASIL PENELITIAN DAN PEMBAHASAN}

Setelah penelitian mendapatkan data berat badan dan tinggi badan siswa, langkah selanjutnya menghitung IMT setiap siswa dan memasukkannya dalam tabel IMT, adapun hasilnya adalah sebagai berikut:

1.Data perkelas

2.Data keseluruhan

Data hasil penelitian di setiap kelas dapat dilihat pada tabel di bawah ini:

Tabel 1 Hasil IMT kelas IV

\begin{tabular}{rlrr} 
No & Kategori & Jumlah & $\begin{array}{c}\text { Persentase } \\
(\mathbf{\%})\end{array}$ \\
\hline $\mathbf{1}$ & Sangat & 4 & 14.28 \\
& Kurus & & \\
\hline $\mathbf{2}$ & Kurus & 3 & 10.71 \\
\hline $\mathbf{3}$ & Normal & 11 & 4.82 \\
\hline $\mathbf{4}$ & Gemuk & 3 & 10.71 \\
\hline $\mathbf{5}$ & Obesitas & 7 & 25
\end{tabular}

Berdasarkan tabel tersebut di atas siswa kelas IV yang mengalami sangat kurus sebanyak 4 anak (14.28 \%), siswa yang mengalami kurus sebanyak 3 anak (10.71\%), siswa yang dinyatakan normal sebanyak 11 anak (4.82\%), siswa yang dinyatakan gemuk sebanyak 3 anak (10.71 $\%)$ dan siswa yang mengalami obesitas sebanyak 7 anak (25\%).

Tabel 2 Hasil IMT kelas V 


\begin{tabular}{rlrr}
\hline No & Kategori & Jumlah & \multicolumn{1}{c}{$\begin{array}{c}\text { Persentase } \\
(\mathbf{\%})\end{array}$} \\
\hline $\mathbf{1}$ & $\begin{array}{l}\text { Sangat } \\
\text { Kurus }\end{array}$ & 7 & 25.92 \\
\hline $\mathbf{2}$ & Kurus & 2 & 7.40 \\
\hline $\mathbf{3}$ & Normal & 10 & 37.03 \\
\hline $\mathbf{4}$ & Gemuk & 3 & 11.11 \\
\hline $\mathbf{5}$ & Obesitas & 5 & 18.51 \\
\hline
\end{tabular}

Berdasarkan tabel tersebut di atas siswa kelas $\mathrm{V}$ yang mengalami sangat kurus sebanyak 7 anak (25.92 \%), siswa yang mengalami kurus sebanyak 2 anak (7.42 $\%$, siswa yang dinyatakan normal sebanyak 10 anak (37.03\%), siswa yang dinyatakan gemuk sebanyak 3 anak (11.11 \%) dan siswa yang mengalami obesitas sebanyak 5 anak (18.51\%).

\begin{tabular}{llrr}
\hline No & Kategori & Jumlah & $\begin{array}{c}\text { Persentase } \\
(\%)\end{array}$ \\
\hline $\mathbf{1}$ & $\begin{array}{l}\text { Sangat } \\
\text { Kurus }\end{array}$ & 0 & 0 \\
\hline $\mathbf{2}$ & Kurus & 5 & 19.23 \\
\hline $\mathbf{3}$ & Normal & 8 & 30.76 \\
\hline $\mathbf{4}$ & Gemuk & 3 & 11.52 \\
\hline $\mathbf{5}$ & Obesitas & 10 & 38.46 \\
\hline
\end{tabular}

Tabel 3 Hasil IMT kelas VI

Berdasarkan tabel tersebut di atas siswa kelas VI yang mengalami sangat kurus sebanyak 0 anak (0 \%), siswa yang mengalami kurus sebanyak 5 anak (19.23 $\%$, siswa yang dinyatakan normal sebanyak 8 anak (30.76\%), siswa yang dinyatakan gemuk sebanyak 3 anak (11.52
\%) dan siswa yang mengalami obesitas sebanyak 10 anak (38.46\%).

Tabel 4 Hasil IMT kelas IV-VI

\begin{tabular}{rlrc}
\hline No & Kategori & Jumlah & $\begin{array}{c}\text { Persentase } \\
(\mathbf{\%})\end{array}$ \\
\hline $\mathbf{1}$ & $\begin{array}{l}\text { Sangat } \\
\text { Kurus }\end{array}$ & 11 & 13.58 \\
\hline $\mathbf{2}$ & Kurus & 10 & 12.34 \\
\hline $\mathbf{3}$ & Normal & 29 & 35.80 \\
\hline $\mathbf{4}$ & Gemuk & 9 & 11.11 \\
\hline $\mathbf{5}$ & Obesitas & 22 & 27.16 \\
\hline
\end{tabular}

Berdasarkan tabel tersebut di atas siswa kelas atas dari kelas IV-VI yang mengalami sangat kurus sebanyak 11 anak (13.58\%), siswa yang mengalami kurus sebanyak 10 anak (12.34 \%), siswa yang dinyatakan normal sebanyak 29 anak $(35.80 \%)$, siswa yang dinyatakan gemuk sebanyak 9 anak $(11.11 \%)$ dan siswa yang mengalami obesitas sebanyak 22 anak (27.16\%). Apabila dilihat dari tabel IMT, sebanyak $27.16 \%$ siswa SD Negeri Randusari kelas atas yang mengalami obesitas mempunyai latar belakang bermacam-macam yang mengakibatkan mereka mengalami obesitas, ditinjau dari faktor genetik, pola makan dan aktivitas fisik.

Pola makan yang berlebihan jika tidak didukung dengan aktivitas fisik yang cukup dan teratur membuat energi yang 
seharusnya dikeluarkan justru akan tersimpan dan akhirnya menjadi lemak dalam tubuh. Kurangnya aktivitas juga dapat membuat kurangnya pemakaian energi pada tubuh, dengan adanya alat komunikasi dan tekhnologi yang semakin maju dan berkembang anak lebih suka cenderung bermain game dan internet daripada permainan yang menguras energi dan tenaga yang cukup banyak misalnya, bermain kejarkejaran, lompat tali dan boiboian.

Budaya makan cepat saji yang sangat digemari oleh anak-anak sehingga membuat perkembangan dan pertumbuhan anak semakin tidak sehat. Meskipun makanan cepat saji pada umumnya rasanya nikmat tapi tidak ada kandungan gizi. Makanan cepat saji atau fast food umumnya mengandung lemak dan gula yang tinggi yang menyebabkan obesitas.

Berdasarkan wawancara pada orang tua yang mengalami obesitas rata-rata orang tua mereka termasuk golongan ekonomi menengah ke atas sehingga pemenuhan nutrisi bisa terpenuhi bahkan berlebihan hampir sebagian besar masih mengkonsumsi susu 2-3 kali sehari, selain itu faktor silsilah keluarga beberapa anak yang obesitas adalah anak tunggal dan anak bungsu dengan keadaan demikian sehingga mereka sering dimanja oleh keluarga. Jadi faktor-faktor yang menjadi penyebab obesitas pada siswa SD Negeri Randusari adalah genetik keluarga, pola makan dan aktivitas fisik yang kurang dilakukan oleh siswa.

\section{SIMPULAN}

Berdasarkan analisis data dan pembahasan yang telah diuraikan dalam bab sebelumnya, penulis dapat menarik kesimpulan bahwa ketidakseimbangan antara energi input (pola makan) dengan energi output (aktifitas fisik) berpengaruh secara signifikan terhadap kejadian kegemukan (obesitas), sedangkan 27.16\% dari keseluruhan anak kelas atas yang mengalami obesitas. Faktor genetik keluarga, pola makan dan aktivitas fisik yang kurang dilakukan oleh siswa yang menyebabkan anak mengalami obesitas. 


\section{DAFTAR PUSTKA}

Biro FM, Wien M. (2010). Childhold Obesity and Adult Morbidities. Am J Clin Nutr,; 91: 1499-1505.

Dewi MR, Sidiartha IGL. 2013. Prevalensi dan Faktor Resiko Obesitas Anak Sekolah Dasar di Daerah Urban dan Rural.Medicina.; 44: 15-21.

height and weight in rural and urban populations in low-income and middleincome countries: a systematic analysis ofpopulation-representative data. Lancet Glob Health; 1: 300-309.
Kementerian Kesehatan RI.2013. Riset Kesehatan Dasar Jakarta: Kementerian Kesehatan RI; 2013.

Onis M, Bloosner M, Borghi E.2008.Global prevalence and trends of overweight and obesity amongpreschool children. Am J Clin Nutr.;92: 1257-1264.

Paciorek CJ, Stevens GA, Finucane MM. 2013. Children's 
Setyawan, Identifikasi Faktor 